\title{
Longitudinal zonation of larval Hydropsyche (Trichoptera: Hydropsychidae): abiotic environmental factors and biotic interactions behind the downstream sequence of Central European species
}

\author{
Márk Ficsór (1D · Zoltán Csabai $(\mathbb{D}$
}

Received: 27 January 2021/Revised: 13 April 2021/ Accepted: 21 April 2021/Published online: 13 May 2021

(C) The Author(s) 2021

\begin{abstract}
The aim of this review is to summarize the literature knowledge about how abiotic environmental factors and biotic interactions affect the sequentially overlapping longitudinal distribution of Central European species of the net-spinning freshwater caddisfly larvae of the genus Hydropsyche (Trichoptera: Hydropsychidae). In this relation, several physical and chemical parameters of water are discussed, as well as different species-specific traits, behavioural aspects and the interaction of coexisting species. Longitudinal gradients of river networks, especially annual temperature range, flow velocity and the particle size of suspended food material play a crucial role in forming the downstream succession of characteristic species, while increased levels of organic pollution, nutrients, salinity and heavy metals
\end{abstract}

Handling editor: Verónica Ferreira

M. Ficsór $(\square)$

Department of Public Health, Laboratory for

Environmental Protection, Government Office of Borsod-

Abaúj-Zemplén County, Miskolc, Hungary

e-mail: ficsor.mark@borsod.gov.hu

M. Ficsór · Z. Csabai

Department of Hydrobiology, Faculty of Sciences,

University of Pécs, Pécs, Hungary

e-mail: csabai@gamma.ttk.pte.hu

Z. Csabai

Department of Botany and Zoology, Faculty of Sciences, Masaryk University, Brno, Czechia facilitates the presence of more tolerant ones. Several species-specific traits, such as respiration range, netbuilding frequency, head capsule size or optimal netbuilding velocity correlate with the position of a given species in the sequence. Coexistence of species with similar ecological demands in the overlapping zones of distribution is facilitated by differences in feeding and net-building habits, microhabitat preferences and staggering life cycles, but complicated at the same time by means of inter- and intraspecific territorial behaviour, such as fighting for the ownership of larval retreats or the practice of stridulation.

Keywords Hydropsychidae - Longitudinal distribution $\cdot$ Abiotic factors $\cdot$ Biotic interactions

\section{Introduction}

A fundamental concept of ecology is that organisms exist in a multidimensional space, a so called niche, where the dimensions-interpreted as hypothetical axes of various quantifiable environmental factorshave impacts on one particular organism or population which, in return has responses and also possible impacts on these factors (Hutchinson, 1957; MacArthur \& Levins, 1967; Schoener, 1989; Chase $\&$ Leibold, 2003). The number of types, forms, measures and scales of such factors is vast and their 
importance is well known at all ecological (i.e. individual, population, species, community and ecosystem) levels (e.g. Hynes, 1970; Dunson \& Travis, 1991; Jackson et al., 2001; Bornette \& Puijalon, 2011; González-Salazar et al., 2013; Zellweger et al., 2016). Identifying these factors and modelling their effects on the distribution of species is a key issue in ecology (Araujó \& Guisan, 2006; Ashcroft et al., 2011).

Environmental factors and processes acting at different scales from the level of individual biotic interactions to the effect of different temperature regimes are considered to be the key driving forces behind species' distribution either viewed from their local abundances in a counteracting metacommunity of populations or their presence-absence in a certain geographical area (Weiher \& Keddy, 1999; Soberón, 2010; Boulangeat et al., 2012; Thuiller et al., 2015).

Being exceptionally rich and diverse considering their fauna and flora, yet showing distinctive similarities worldwide regarding longitudinal structure, dynamics, environmental gradients and functional species groups (Illies, 1961; Cummins, 1974; Vannote et al., 1980; Statzner, 1987; Schmidt-Kloiber et al., 2017; Englmaier et al., 2020), riverine ecosystems are thoroughly studied sites for understanding the role of environmental factors in the spatiotemporal distribution of freshwater species.

Benthic invertebrates, one of the most prominent functional group of aquatic organisms (Faith \& Norris, 1989; Resh \& Rosenberg, 1993; Wallace \& Webster, 1996) are found in most lotic freshwater habitats, where they are key components of aquatic food webs and develop high diversity both from taxonomical and functional point of view (Hellawell, 1986). Due to their sedentary lifestyle and a wide range of sensitivities and tolerance of nearly any nature of changes in both water quality and habitat characteristics, their distribution is the result of site-specific ecological conditions at almost every spatial scale from microhabitats to whole river networks (Richards et al., 1997; Dolédec et al., 2000; Malmqvist, 2002; Li et al., 2001, 2010).

The net-spinning larvae of Hydropsychid caddisflies (Trichoptera: Hydropsychidae) have been the subject of ecological investigation since the 1970's due to (1) their essential service as filter-feeders/collectors and processors of suspended organic materials (Cummins, 1973; Wallace et al., 1977; Fuller \&
Mackay, 1980; Wallace \& Merritt, 1980; Hauer \& Stanford, 1982); (2) the variety of their pollution and disturbance tolerance among species-therefore their use as bio-indicators (Higler \& Tolkamp, 1983; Hellawell, 1986; Dohet, 2002; Houghton, 2004); (3) their importance as ecosystem engineers, since they physically modify, maintain and create their own habitat substrate (see Cardinale et al., 2004; Maguire et al., 2020); and (4) most notably the species' wellpronounced longitudinal zonation along the streamriver continuum, which is considered to be the result of combined effects of several abiotic, biotic and (bio)geographical factors (e.g. Décamps, 1968; Badcock, 1974; Gordon \& Wallace, 1975; Wiggins \& Mackay, 1978; Hildrew \& Edington, 1979; Ross \& Wallace, 1982; Dolédec \& Tachet, 1989; Roux et al., 1992).

The aim of the current review is to summarize and discuss the literature and knowledge about the environmental factors and biotic interactions influencing the longitudinal distribution of larval Hydropsychidae with special reference to Central European species of the genus Hydropsyche Pictet, 1834, establishing a baseline inventory for further research and application of the group as model organisms. As the identification and compilation of decisive environmental factors are basic and inevitable steps of descriptive or predictive species distribution modelling-a widespread design in aquatic ecology — we would also highlight the need of similar works for other freshwater faunal groups and other geographic areas.

\section{Central European species of the genus Hydropsyche and the longitudinal sequence}

In Central Europe-defined by Waringer \& Graf (2011) as Austria, Germany and Switzerland with the whole extent of Ecoregion 9 (Illies, 1978), and expanded here to include Ecoregion 11 (Hungarian Lowlands) (see Fig. 1) -20 species of the genus Hydropsyche are known (Neu \& Tobias, 2004; Graf et al., 2008; Waringer \& Graf, 2011), 18 of which are treated in this review (Table 1). Hydropsyche tobiasi Malicky, 1977-a species known only by adult collection specimens-though listed in some sources (e.g. Neu \& Tobias, 2004; Robert, 2004) as a member of the Central European caddisfly fauna, has not been caught since 1938, and widely considered to be extinct 


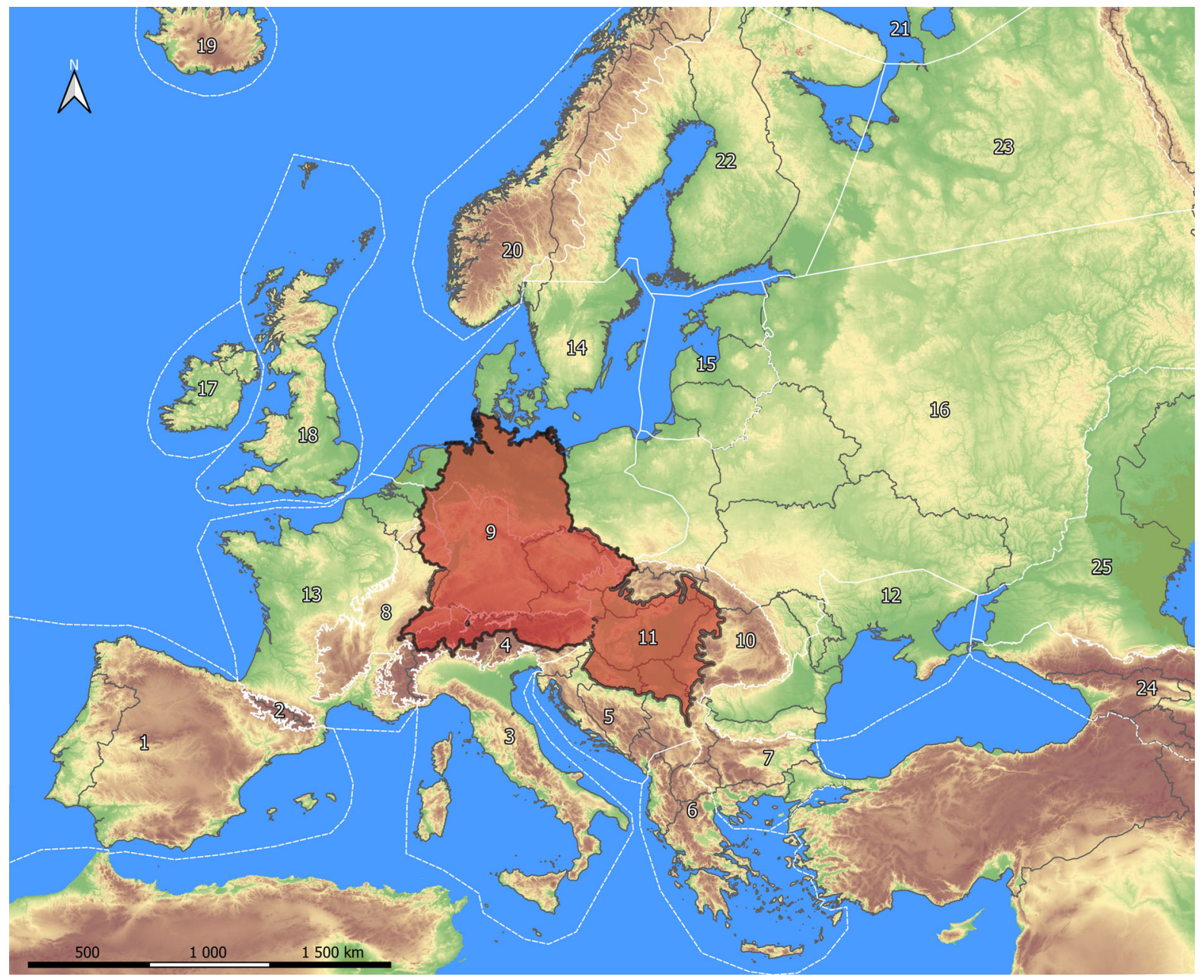

Fig. 1 Map showing the Central European area covered in this review (darkened). It includes Austria, Germany and Switzerland as well as the whole extent of European Ecoregion 9 and 11

(Malicky, 2014), thus not treated in this review. The Hydropsyche doehleri Tobias, 1972 has also been excluded from our review, because this species basically has Mediterranean distribution (Calabria, Sicily, Sardinia and Corsica) and its range only marginally reaches the Central European region in the canton of Ticino, Switzerland (Vincentini et al., 2020).

Based on morphological characteristics of the adults, Malicky (1977) and Pitsch (1993) define four species groups (for full species names see Table 1): (1) $H$. instabilis-Group (containing $H$. instabilis, $H$. siltalai, $H$. tenuis, $H$. saxonica and $H$. fulvipes), (2) $H$. pellucidula-Group ( $H$. pellucidula, $H$. incognita, $H$. dinarica and $H$. botosaneanui), (3) H. guttata-Group as proposed by Illies (1978). Numbers refer to European Ecoregions defined by Illies (1978)

(H. guttata, H. bulgaromanorum, $H$. ornatula, $H$. contubernalis, $H$. tobiasi, $H$. modesta, $H$. exocellata and $H$. bulbifera) and (4) $H$. silfvenii-Group (only $H$. silfvenii with central European distribution) with one species, $H$. angustipennis, that cannot be assigned to any of the above-mentioned groups. Different grouping of the genus can also be found in the literature (e.g. Malicky \& Chantaramongkol, 2000), and more recent studies define all Hydropsyche species as part of the $H$. instabilis-Group based on molecular evidence (see Geraci et al., 2010). Larvae of the family generally occur in restricted parts of the stream system. Their sequential distribution extends over almost the entire river continuum from headwaters to large rivers (Fig. 2), and is so pronounced that a stream can be 
Table 1 Main ecological preferences of larvae of 18 Central European Hydropsyche species

\begin{tabular}{|c|c|c|c|c|c|c|c|c|c|c|c|c|c|c|c|c|}
\hline \multirow[t]{2}{*}{ Species } & \multirow[t]{2}{*}{ Abbr. } & \multirow{2}{*}{$\begin{array}{l}\text { Curr. } \\
\text { pref. }\end{array}$} & \multirow{2}{*}{$\begin{array}{l}\text { Temp. } \\
\text { pref. }\end{array}$} & \multirow{2}{*}{$\begin{array}{l}\text { Dil. } \mathrm{O}_{2} \\
\text { pref. }\end{array}$} & \multirow{2}{*}{\multicolumn{2}{|c|}{$\begin{array}{l}\text { Poll. } \\
\text { tol. }\end{array}$}} & \multirow{2}{*}{\multicolumn{2}{|c|}{$\begin{array}{l}\text { Flight } \\
\text { per. }\end{array}$}} & \multicolumn{8}{|c|}{ Stream zonation preference ${ }^{16}$} \\
\hline & & & & & & & & & $e C$ & $h C$ & $e R$ & $m R$ & $h R$ & $e P$ & $m P$ & $h P$ \\
\hline $\begin{array}{l}\text { H. angustipennis (Curtis, } \\
1834)^{1}\end{array}$ & angu & $\boldsymbol{\nabla}$ & $\boldsymbol{\Delta}$ & $\boldsymbol{\nabla}$ & \multicolumn{2}{|c|}{ v.high } & \multicolumn{2}{|c|}{ IV-IX } & - & - & - & 3 & 3 & 3 & 1 & - \\
\hline $\begin{array}{l}\text { H. botosaneanui } \\
\quad \text { Marinkovic, } 1966^{2}\end{array}$ & boto & $n / a$ & $n / a$ & $n / a$ & \multicolumn{2}{|c|}{$n / a$} & \multicolumn{2}{|c|}{ V-VI } & - & - & 2 & 4 & 3 & 1 & - & - \\
\hline $\begin{array}{l}\text { H. bulbifera McLachlan, } \\
1878^{1,3}\end{array}$ & bulb & $\boldsymbol{D}$ & $n / a$ & $n / a$ & \multicolumn{2}{|c|}{ high } & \multicolumn{2}{|c|}{ V-IX } & - & - & - & 1 & 4 & 5 & - & - \\
\hline $\begin{array}{l}\text { H. bulgaromanorum } \\
\text { Malicky, } 1977^{1,4}\end{array}$ & bulg & $\boldsymbol{\nabla}$ & $\boldsymbol{\Delta}$ & $\nabla$ & \multicolumn{2}{|c|}{$\bmod$} & \multicolumn{2}{|c|}{ III-X } & - & - & - & 1 & 3 & 3 & 3 & - \\
\hline $\begin{array}{l}\text { H. contubernalis } \\
\text { McLachlan, } 1865^{1,4}\end{array}$ & cont & $>$ & $\Delta$ & $\nabla$ & \multicolumn{2}{|c|}{ high } & \multicolumn{2}{|c|}{ IV $-\mathrm{X}$} & - & - & - & 1 & 4 & 4 & 1 & - \\
\hline $\begin{array}{l}\text { H. dinarica Marinkovic, } \\
1979^{1,5,6}\end{array}$ & dina & $n / a$ & $\nabla$ & $\boldsymbol{\Delta}$ & \multicolumn{2}{|c|}{ low } & \multicolumn{2}{|c|}{ V-IX } & - & - & 4 & 5 & 1 & - & - & - \\
\hline H. exocellata Dufour, $1841^{7}$ & exoc & $>$ & $n / a$ & $n / a$ & \multicolumn{2}{|c|}{ high } & \multicolumn{2}{|c|}{ IV $-\mathrm{X}$} & - & - & - & - & 2 & 5 & 2 & 1 \\
\hline H. fulvipes (Curtis, 1834) ${ }^{1,3}$ & fulv & $\boldsymbol{\Delta}$ & $\nabla$ & $\boldsymbol{\Delta}$ & & & & & 1 & 7 & 2 & - & - & - & - & - \\
\hline H. guttata Pictet, $1834^{1,3}$ & gutt & $>$ & $>$ & $n / a$ & & & & & - & - & - & - & 5 & 4 & 1 & - \\
\hline H. incognita Pitsch, $1993^{1,9}$ & inco & $\Delta$ & $n / a$ & $\Delta$ & & & & & - & - & - & 5 & 4 & 1 & - & - \\
\hline $\begin{array}{l}\text { H. instabilis (Curtis, } \\
1834)^{1,3,10}\end{array}$ & inst & $\boldsymbol{\Delta}$ & $\boldsymbol{\nabla}$ & 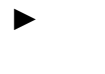 & & & & & - & - & 4 & 4 & 2 & - & - & - \\
\hline H. modesta Navas, $1925^{1,3,6}$ & mode & $>$ & $\boldsymbol{\Delta}$ & $n / a$ & & & $\mathrm{~V}-$ & & - & - & - & 2 & 2 & 2 & 2 & 2 \\
\hline $\begin{array}{l}\text { H. ornatula McLachlan, } \\
1878^{3,11}\end{array}$ & orna & $n / a$ & $n / a$ & $n / a$ & & & & & - & - & - & - & 3 & 4 & 3 & - \\
\hline $\begin{array}{l}\text { H. pellucidula (Curtis, } \\
1834)^{1,3,12}\end{array}$ & pell & $\Delta$ & 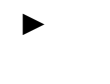 & $\boldsymbol{\Delta}$ & & & $\mathrm{V}_{-}$ & & - & - & 1 & 2 & 4 & 3 & - & - \\
\hline $\begin{array}{l}\text { H. saxonica McLachlan, } \\
1884^{1,13}\end{array}$ & saxo & $\boldsymbol{\Delta}$ & $\nabla$ & $\boldsymbol{\Delta}$ & & & & & - & 2 & 6 & 2 & - & - & - & - \\
\hline H. silfvenii Ulmer, $1906^{3,14}$ & silf & $\boldsymbol{\Delta}$ & $\boldsymbol{\nabla}$ & $n / a$ & & & $\mathrm{~V}-$ & & - & - & - & 4 & 6 & - & - & - \\
\hline H. siltalai Döhler, $1963^{1,3}$ & silt & $\boldsymbol{\Delta}$ & $n / a$ & $n / a$ & & & & & - & - & 1 & 5 & 4 & - & - & - \\
\hline H. tenuis Navas, $1932^{1,15}$ & tепи & $\boldsymbol{\Delta}$ & $\boldsymbol{\nabla}$ & $\boldsymbol{\Delta}$ & & & & & - & - & 8 & 2 & - & - & - & - \\
\hline Species & & & pref. $^{16}$ & & $\mathrm{Hyc}$ & pre & & & & $\mathrm{pH}^{16}$ & & Feed & ty & & & \\
\hline & & & $28 h$ & $\overline{l 2 h}$ & eup & & $r p$ & pap & & & & $g a$ & $g r$ & & $p f f$ & $\overline{p r}$ \\
\hline H. angustipennis (Curtis, 183 & & 0 & 1 & 1 & 8 & 2 & & - & & $\mathrm{ac}$ & & - & 2 & & 5 & 3 \\
\hline H. botosaneanui Marinkovic, & $1966^{2}$ & 1 & 1 & 0 & - & - & & - & & $n / a$ & & - & 2 & & 5 & 3 \\
\hline H. bulbifera McLachlan, 187 & & 1 & 1 & 1 & 8 & 2 & & - & & $n / a$ & & - & 2 & & 5 & 3 \\
\hline H. bulgaromanorum Malicky & $1977^{1,4}$ & 0 & 1 & 1 & 7 & 2 & & 1 & & $n / a$ & & - & 2 & & 5 & 3 \\
\hline H. contubernalis McLachlan, & $1865^{1,4}$ & 0 & 1 & 1 & 8 & 2 & & - & & $n / a$ & & 1 & - & & 8 & 1 \\
\hline H. dinarica Marinkovic, 197 & & 1 & 1 & 1 & - & - & & - & & $n / a$ & & - & 2 & & 5 & 3 \\
\hline H. exocellata Dufour, $1841^{7}$ & & 0 & 1 & 1 & 10 & - & & - & & $n / a$ & & - & 2 & & 5 & 3 \\
\hline H. fulvipes (Curtis, 1834) & & 1 & 1 & 1 & 10 & - & & - & & ne-al & & - & 2 & & 5 & 3 \\
\hline H. guttata Pictet, $1834^{1,3}$ & & - & - & - & 10 & - & & - & & $n / a$ & & - & 2 & & 5 & 3 \\
\hline H. incognita Pitsch, $1993^{1,9}$ & & 1 & 1 & 1 & 10 & - & & - & & $n / a$ & & - & 2 & & 5 & 3 \\
\hline H. instabilis (Curtis, 1834) $)^{1,3}$ & & 1 & 1 & 1 & 10 & - & & - & & ne-al & & - & 2 & & 5 & 3 \\
\hline H. modesta Navas, $1925^{1,3,6}$ & & 0 & 1 & 1 & 8 & 2 & & - & & $n / a$ & & - & 2 & & 5 & 3 \\
\hline H. ornatula McLachlan, 1878 & & 0 & 1 & 1 & 10 & - & & - & & $n / a$ & & - & 2 & & 5 & 3 \\
\hline H. pellucidula (Curtis, 1834) & & 1 & 1 & 1 & 10 & 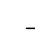 & & - & & $\mathrm{ac}$ & & - & 2 & & 5 & 3 \\
\hline H. saxonica McLachlan, 188 & & 0 & 1 & 1 & 10 & - & & - & & $n / a$ & & - & 2 & & 5 & 3 \\
\hline
\end{tabular}


Table 1 continued

\begin{tabular}{|c|c|c|c|c|c|c|c|c|c|c|c|}
\hline \multirow[t]{2}{*}{ Species } & \multicolumn{3}{|c|}{ Alt. pref. ${ }^{16}$} & \multicolumn{3}{|c|}{ Hydr. pref. ${ }^{16}$} & \multirow[t]{2}{*}{$\mathrm{pH}^{16}$} & \multicolumn{4}{|c|}{ Feeding type ${ }^{16}$} \\
\hline & $g 8 h$ & $28 h$ & $l 2 h$ & eup & prp & pap & & $g a$ & $g r$ & $p f f$ & $p r$ \\
\hline H. silfvenii Ulmer, $1906^{3,14}$ & 0 & 1 & 0 & 10 & - & - & $n / a$ & - & 2 & 5 & 3 \\
\hline H. siltalai Döhler, $1963^{1,3}$ & 0 & 1 & 1 & 10 & - & - & ind & - & 2 & 5 & 3 \\
\hline H. tenuis Navas, $1932^{1,15}$ & - & - & - & - & - & - & $n / a$ & - & 2 & 5 & 3 \\
\hline
\end{tabular}

References for the species and preference values are indicated in upper indices

Curr. pref.-current preference, Temp. pref.-temperature preference, Dil. $\mathrm{O}_{2}$ pref.-preference for diluted oxygen content $(\boldsymbol{\Delta}-$ high, -moderate, $\boldsymbol{\nabla}$-low), Poll. tol.-tolerance of (organic) pollution, Flight per.-flight period (number of months in latin numerals). Stream zonation preference (in ten-point assignment system): eC-eucrenal, hC-hypocrenal, eR-epirhithral, mRmetarhithral, $\mathrm{hR}$ - hyporhithral, eP-epipotamal, $\mathrm{mP}$ - metapotamal, $\mathrm{hP}$-hypopotamal). Altitude preference in presence/absence assignment system: g8h-above $800 \mathrm{~m}$ AMSL (above mean sea level), 28h-between 200 and $800 \mathrm{~m}$ AMSL, $12 \mathrm{~h}$-below $200 \mathrm{~m}$ AMSL. Hydrologic preference: eup—eupotamon, prp—parapotamon, pap—palaeopotamon, $\mathrm{pH}$ preference: ac—acidic, ne-al— neutral to alkaline, ind—indifferent). Feeding type in ten-point assignment system: ga—gatherer/collector, gr-grazer, pff—-passive filter feeder, $\mathrm{pr}$ - predator. $n / a$ : data insufficient or not available

1: Lechthaler \& Stockinger (2005); 2: Neu \& Fischer (2002); 3: Waringer \& Graf (1997); 4: Czachorowski \& Serafin (2004); 5: De Soto et al. (1994); 6: Roux et al. (1992), 7: Guinand et al. (1994); 8: Usseglio-Polatera \& Bournaud (1989); 9: Pîrvu et al. (2015); 10: Philipson (1954); 11: Malicky (1977); 12: Becker (1987); 13: Hrovat \& Urbanič (2012); 14: Coppa (2015); 15: Pitsch (1993), 16: Graf et al. (2008)

divided to specific sections characterized by different species and their combinations (Higler \& Tolkamp, 1983; Statzner \& Dolédec, 2011). Larval Hydropsychidae typically colonize hard bottom substrates of different types and particle sizes, where they build retreats consisting of silk and substrate material with specific mesh sized catch-nets attached, facilitating their filter feeding through five larval instars. Adults of early-swarming species (e.g. H. angustipennis, $H$. bulgaromanorum or $H$. contubernalis) fly from March or April while most are on wing from May to September (Waringer \& Graf, 1997).

The stream section-specific Hydropsyche larval assemblages correspond well with the taxonomical species groups suggested by Malicky (1977) and Pitsch (1993), so hereinafter these species-group names are used for the assemblages too. Most species of the $H$. instabilis-Group inhabit headwaters and mountainous or colline small or medium sized streams (crenal and rhithral zones) while those of the $H$. pellucidula-Group are usually found in streams and rivers of the middle sections (rhithral zones) of river networks. Species of the $H$. guttata-Group live in medium sized watercourses of the lower sections of the rhithral zone and particularly in larger rivers of the potamal zones (Table 1). Larvae of $H$. angustipennis colonize mainly rivers and streams of variable size in lower regions (Botosaneanu \& Malicky, 1978; Edington \& Hildrew, 1995) but can also be found in headwaters (Pitsch, 1993). H. silfvenii lives in smaller streams of the rhithral zone with lower mean water temperature, higher current velocities and gravel rich bottom (Lechthaler \& Stockinger, 2005; Coppa, 2015).

The longitudinal sequence of larval Hydropsyche, although being affected by the species' areas of distribution, shows high similarities in many European watercourses and catchment areas. For example, in the case of unpolluted British running waters the sequence is typically inst-silt-pell-cont (Edington \& Hildrew, 1995), in the Loire it was found to be dina/inst-siltinco-(angu)-exoc-orna-cont-bulg, while in the Rhône catchment to be dina-inst-silt-(angu)-inco-cont-ornaexoc (cited by Statzner \& Dolédec, 2011). Higler \& Tolkamp (1983) described the sequence of Dutch species as fulv-saxo-silt-inst-pell-(angu)-exoc-ornacont, although $H$. exocellata and $H$. ornatula are reported to be disappeared and $H$. bulgaromanorum to be appeared in larger rivers of the Netherlands (Higler et al., 2008). Based on the comprehensive work of Graf et al. (2008) on the distribution and quantified ecological preferences of Trichoptera, a summarized 


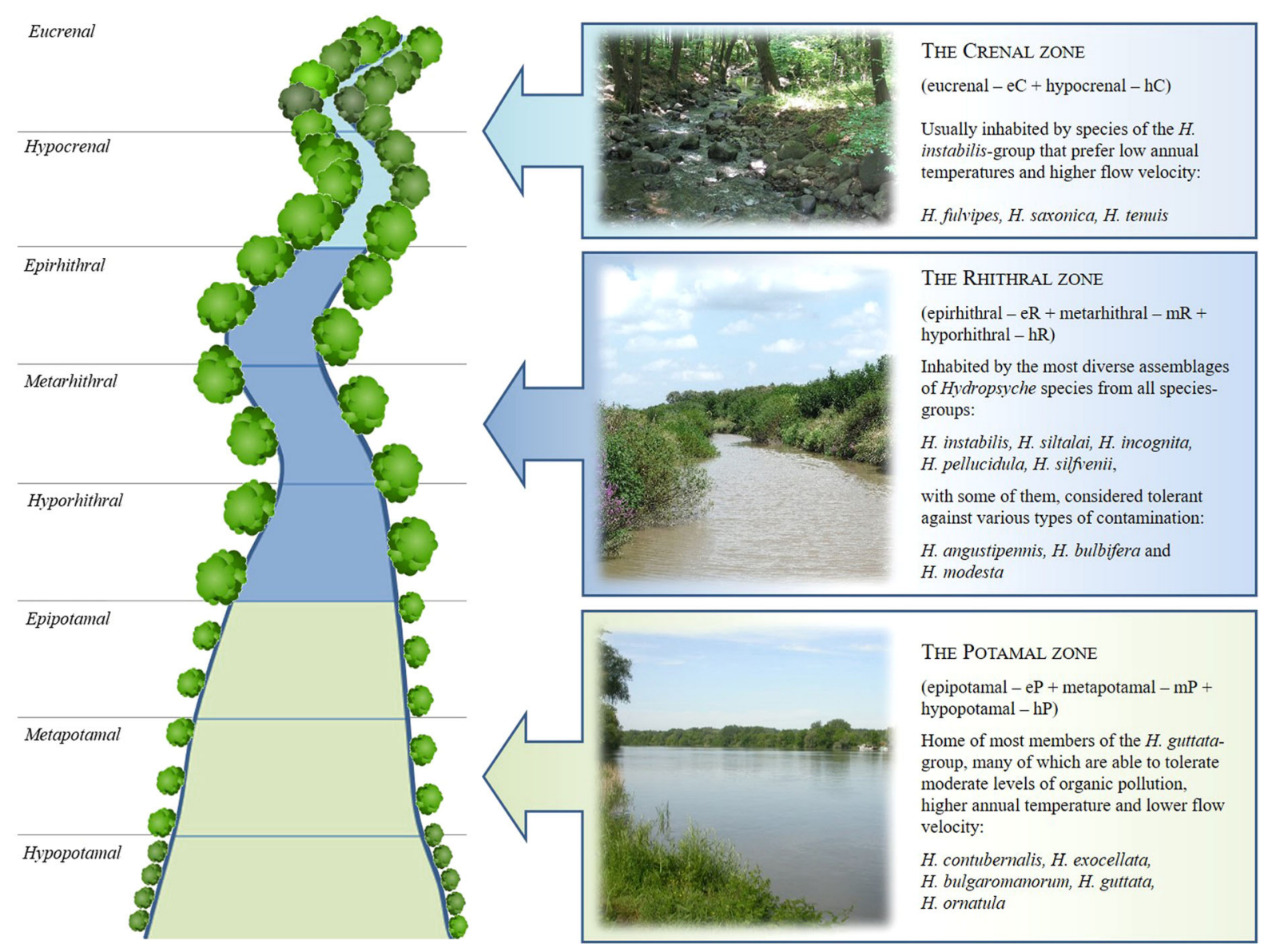

Fig. 2 Schematic and generalized view of the river continuum with the major and minor zones. Larvae of certain Hydropsyche species or species groups are characteristics for different parts of

downstream sequence of 18 Central European species as fulv-saxo-tenu-dina-inst-silt-boto-pell-inco-silf(angu)-(bulb)-(mode)-cont-bulg-gutt-orna-exoc can be given (see Fig. 3). This sequence, however, is merely hypothetical, strongly affected by numerous environmental conditions, biased by coexistence, highly overlapping and never as complete in nature as listed here due to different geographical distribution of species. It is also notable that some species, that are less sensitive to moderate pollution levels (e.g. $H$. angustipennis, $H$. bulbifera or $H$. modesta-indicated in brackets above) do not really belong to the downstream sequence, but tend to inhabit stretches, where conditions are not suitable for less tolerant members of the genus (Higler \& Tolkamp, 1983; Camargo, 1991; Statzner \& Dolédec, 2011). Despite being quite common and similar in several central and the stream system. Their sequential distribution extends over almost the entire river continuum from headwaters to large rivers

western parts of the continent, deviations from the sequence shown in Fig. 3, have been reported from some Iberian rivers, most notably the occurrence of $H$. exocellata in headwaters (Bonada et al., 2004) and the coexistence of it with $H$. siltalai and $H$. instabilis in middle and lower reaches (see Puig et al., 1987; Valladolid et al., 2007) This is possibly due to the different characteristics of the Ibero-Macaronesian ecoregion, but still calling for further inspection, since other Iberian studies (e.g. Gallardo-Mayenco et al., 1998) have shown sequences comparable to those of Central European river networks. 


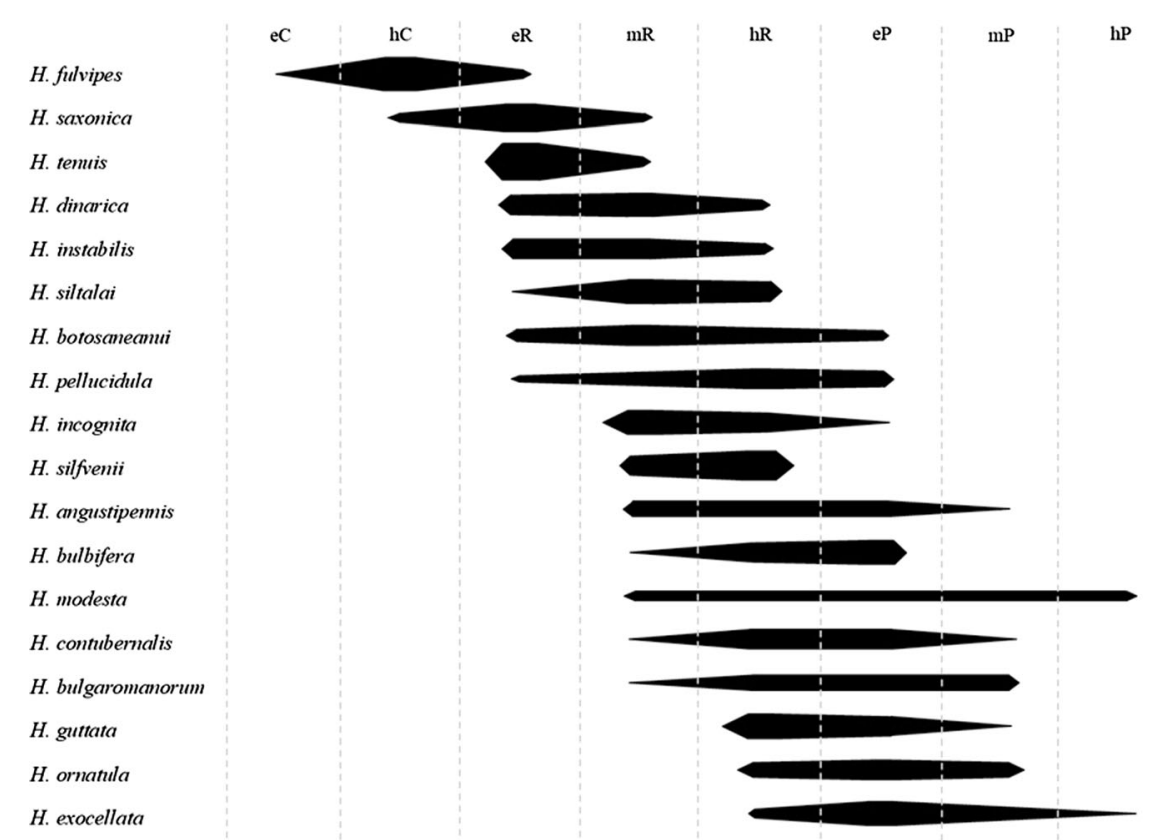

Fig. 3 Longitudinal distributional sequence of Hydropsyche species according to their stream zonation preference based on the data of Graf et al. (2008). Species are ordered by their first appearance and highest preference values along the river continuum. The width of plot lines corresponds with values of

\section{Abiotic factors influencing the distribution of larval Hydropsyche}

Longitudinal gradient related and natural physical characteristics

Annual temperature range typically increases along the stream-river continuum towards the estuaries, but the longitudinal sequence of the species most probably is not directly related to temperature, and rather could be linked to the temperature-dependent larval metabolism (Statzner \& Dolédec, 2011; Cogo et al., 2020). Although it is unlikely that the sequence of the species is the result of lethal limits in water temperature, the relationship between temperature ranges and respiratory or metabolic rates are well defined and different among species (Edington \& Hildrew, 1973; Howell \& Voshhell, 1982; Bales \& Badcock, 1987). Hildrew \& Edington (1979) showed that acceleration of the respiration rate occurs at progressively higher temperatures in the downstream sequence of hydropsychid species Diplectrona felix, Hydropsyche instabilis and $H$. pellucidula in river Usk (South Wales), which is a clear sign of accommodation of downstream preference for the indicated zones. $e C$ eucrenal zone, $h C$ hypocrenal zone, $e R$ epirhithral zone, $m R$ metarhithral zone, $h R$ hyporhithral zone, $e P$ epipotamal zone, $m P$ metapotamal zone, $h P$ hypopotamal zone

species to higher temperature regimes. It also comes with an upwards extension of the range where these species show relative temperature independence, thus having extended thermal tolerance. A similar downstream succession of $H$. dinarica, $H$. siltalai, $H$. pellucidula $H$. contubernalis and $H$. modesta was observed in the Rhône river and its tributaries by the comparison of total amplitude of metabolism values, which represent the range of mean oxygen consumption of the respective species between 5 and $25^{\circ} \mathrm{C}$ and which can be treated as a species-trait correlated with longitudinal zonation (Roux et al., 1992), so much so that the position of a given species in the sequence can be defined based on it (Guinand et al., 1994).

The effect of flow velocity on the distribution of Hydropsyche has been investigated in several studies in different ecoregions. It is established that specialization for living at different flow velocities is reflected in the species' respiratory physiology and in the form and success of their net-spinning activities (Hildrew \& Edington, 1979). For European species Tachet et al. (1992) remarks that the downstream trend in species succession depends on the species' ability to spin a catch net when the current velocity decreases. In 
general, net-spinning activity of species living in the crenal or upper-rhithral zones increases with increasing velocity (e.g. in the case of $H$. instabilis, $H$. siltalai or $H$. angustipennis) but decreases after reaching a maximum, showing rather ubiquitous flow preference in case of species of middle reaches and the potamon, like $H$. pellucidula, $H$. contubernalis or $H$. modesta (Philipson, 1954; Edington, 1965; 1968; Becker, 1987; Tachet et al., 1992). Although the differences are slight, they on the one hand allow downstream species with broader velocity spectra to colonize slower patches of middle river sections where riffles and pools occur together (Boon, 1978), and on the other hand they provide the possibility for coexisting species to partition common habitats within the same river section (Hildrew \& Edington, 1979).

The amount of dissolved oxygen also has an impact on the distribution of net-spinning caddisflies primarily by the means of net-spinning activity and behavioural changes, although its effects are highly correlated with current velocity. Long-term experiments concerning the net-building activity and larval development of Hydropsyche species showed that euryoecious species, such as $H$. contubernalis, are able to build capture nets with regular meshes at an $\mathrm{O}_{2-}$ saturation of only $30 \%$ and half of the examined larvae developed into adults at $50 \%$. The less tolerant $H$. pellucidula reacts more severely to a reduction in $\mathrm{O}_{2}$ concentration, so that development into an imago is no longer possible below a saturation of $85 \%$ (Becker, 1987). Under experimental conditions in still water with decreasing oxygen concentration the swift-water species, H. instabilis become immobilized at relatively higher values compared to those found for slowwater species. This difference, however, disappears provided the water is flowing or stirred, and larvae can also compensate for low oxygen concentration by current-producing abdominal movements (Philipson, 1954, 1969; Philipson \& Moorhouse, 1974). Rarely being a lethal or exclusively limiting factor in their natural habitats, dissolved oxygen still considered important in the sequential distribution of the genus, as showed in the case of $H$. incognita (Pîrvu et al., 2015), $H$. dinarica and H. siltalai (Roux et al., 1992) and also H. angustipennis (Vuori, 1995; van der Geest, 2007) in addition to the above mentioned.

The downstream reduction of riverbed particle size has been recognized long ago (e.g. Sternberg, 1875) and several authors established a relation between the longitudinal distribution of different hydropsychid species and the structure of their nets, defining that species of small rivers spin nets with larger meshes than those of large rivers (Wallace, 1975; Wallace et al., 1977; Alstad, 1980, 1982; Fuller \& Mackay, 1980; Fuller et al., 1983). The suggestion that net structures, especially the size of their meshes are directly related to sediment particle size comes easy, yet later studies showed that the differences of the net, though being obvious among, but less within species groups, can not be related to the longitudinal distribution of larvae (Tachet et al., 1987) and that it is most likely the result of the differences in the size of the suspended food material available (Alstad, 1982).

In a study on the distribution of $H$. incognita Pîrvu et al. (2015) defined $\mathrm{pH}$ as the most important physicochemical variable influencing the species distribution. However, no similar evidences are available for other European net-spinning caddisfly species, which suggests that changes of $\mathrm{pH}$ in natural environments affects Hydropsychidae only in extreme cases, i.e. when localized acidic pollution is obvious. Hesthagen et al. (2011) contributes the reappearance of $H$. siltalai in the tributaries of Lake Saudlandsvatn to the improvement of water quality, especially $\mathrm{pH}$. According to Vuori (1995), runoff from acid sulfate soils can cause morphological abnormalities and restrict the distribution of more sensitive species, such as $H$. siltalai, while has less impact on the more tolerant $H$. angustipennis. Regerand et al. (2002) revealed the toxic effect of low $\mathrm{pH}$ on the lipid metabolism of $H$. contubernalis, but also point out that even small changes in $\mathrm{pH}$ initiate biochemical adaptation mechanisms thus broaden the tolerance of species, and only serious conditions, such as a decrease below $\mathrm{pH} 4.0$ can suppress their efficiency.

Inorganic factors related to anthropogenic impact

Many studies on the distribution of aquatic macroinvertebrates, including that of net-spinning caddisflies found that increased levels of organic and inorganic forms of phosphorous and nitrogen influence the distribution of these organisms, although the effect is considered indirect (Urbanič \& Toman, 2007). The findings of Vuori (1995), Buczyńska (2013) and Pîrvu et al. (2015) showed that the increased presence of inorganic N- and P-forms can be related-sometimes in a major extent-to the Hydropsyche fauna of 
streams, interpreted by the means of eutrophication processes, such as the consequential enrichment of organic matter or the decrease of dissolved oxygen due to elevated biological and chemical oxygen demand. Toxicity tests showed active migration and higher tolerance of $\mathrm{H}$. exocellata against increased levels of $\mathrm{NO}_{3}-\mathrm{N}$, defining median lethal concentration $(48 \mathrm{~h}$ LC50) at 592,3 mg/l, such conditions, however, occur very rarely under natural conditions and only in case of severe point-source nutrient pollution (Camargo et al., 2005).

Salinity can also have an effect on benthic communities as well as on the distribution of Hydropsychidae depending on the salt sensitivity of species (Zinchenko \& Golovatyuk, 2013). Piscart et al. (2005) found that the abundance of $H$. contubernalis and $H$. pellucidula decreased significantly in relation to the salinity level while $H$. exocellata became more abundant at the same time. Findings of GallardoMayenco et al. (1998) and Gallardo-Mayenco \& Ruíz (2007) also prove H. exocellata to be a salinity tolerant species, but imply at the same time that salinity has an effect on the composition of the assemblages rather than on the distribution of individual species. An example of this is the case of the hydropsychidae fauna of rivers Werra and Weser in Germany, which significantly improved by the decrease of anthropogenic salt-load (Bäthe \& Coring, 2011). The effect of salt pollution, conductivity and different levels of ionic components on Hydropsychidae were also tested by several authors (see Sala et al., 2016), classifying $H$. instabilis as halophobic and $H$. exocellata as halotolerant species.

Heavy metals have complex and hardly acute but rather chronic effects on Hydropsyche species, resulting in growth and/or developmental disorders, or affecting their fecundity, fitness or life cycles (Tszydel et al., 2016). They can be responsible for fluctuating asymmetry in $H$. exocellata (Bonada et al., 2005), changes of larval anal papillae in $H$. pellucidula (Vuori \& Kukkonen, 1996) or faulty construction of filter nets (Tessier et al., 2000), as well as behavioural anomalies in H. siltalai and H. contubernalis (Vuori, 1994) or H. angustipennis (van der Geest et al., 1999). Generally, Hydropsychidae are among the less sensitive taxa of macroinvertebrates considering heavy metal pollution, placed in the middle of a hypothetic scale of tolerance (Barata et al., 2005), with $H$. angustipennis regarded as the most tolerant of them all
(Vuori, 1995). The harmful effects of heavy metals depend on synergistic interactions of many environmental factors, such as water temperature, current velocity and pH (Solà et al., 2004).

Organic pollution

Organic pollution of freshwater ecosystems, in its most general term means the elevated concentrations of organic compounds (usually suspended proteins, carbohydrates, fats and nucleic acids) and microorganisms living on solid particles of them as a substrate. The most typical sources of organic pollution reaching riverine systems are wastewater sewage, agricultural activities and livestock farming (Friberg et al., 2010). Expressed either as the single parameter of biological oxygen demand (BOD) (e.g. European Commission, 2000) or as a part of multimetric indices taking inorganic forms of phosphorous and nitrogen also into account (e.g. IPO-Leclercq \& Maquet, 1987), the level of organic pollution has a complex and inevitable effect on macroinvertebrates and so on net-spinning caddisflies, which are among the most suitable bio-indicator organisms to reflect it (Higler \& Tolkamp, 1983; Hellawell, 1986).

Many studies and authors have categorized Central European Hydropsyche species based on their tolerance against organic pollution, and-as its level usually shows a longitudinal downstream gradient in European river systems (Mishall et al., 1985; Wen et al., 2017)—came to the same conclusions in most cases as follows (Pitsch, 1993; Waringer \& Graf, 1997; Dohet, 2002; Lechthaler \& Stockinger, 2005): (1) species of headwaters, rivulets and small streams of mountainous and hilly regions are the most sensitive to organic pollution, thus restricted to the shortest stretches: H. fulvipes, $H$. saxonica, H. tenuis and $H$. dinarica; (2) a bit more tolerant (but still showing considerable sensitivity) are $H$. incognita, $H$. instabilis and $H$. silfvenii, reaching even the hyporhithral zone in some territories; (3) species mainly living in the middle (rhithral) reaches are more tolerant thus having a broadened and potentially more overlapping place in the downstream sequence (H. pellucidula and $H$. siltalai); (4) $H$. bulbifera, $H$. bulgaromanorum, $H$. contubernalis, $H$. exocellata and $H$. modesta (the latter four inhabiting mainly the lower rhitron and potamon) are considered to be the most tolerant; and (5) $H$. angustipennis, placed at the end of the gradient, being 
able to survive in various types of heavily contaminated waters at different altitudes.

The large range of sensitiveness to organic pollution, provided that other restrictive conditions, such as temperature regime, flow characteristics and microhabitat types are eligible, allows tolerant species to some extent to infiltrate or completely take over sites that become unsuitable for the more sensitive ones that otherwise could be expected (Higler \& Tolkamp, 1983; Vuori, 1995; Stuijfzand et al., 1999) and also allows them to return first to previously abandoned stretches in case of improving water quality (Engels et al., 1996).

\section{Biological characteristics of Hydropsyche species affecting the distribution}

Some species-specific traits, especially respiration range (metabolic rate), current preference, the characteristics of the net and net-building behaviour or the size of the head capsule correspond to the primary position of a given species in the longitudinal sequence of distribution (Fig. 4), and also its possibilities to coexist with others in the same reach. Moreover, these traits show strong relation to the phylogeny of the genus: the downstream increase of respiration range, decrease of the optimal net-building velocity and frequency of net-building with regular meshes at an elevated near-bottom velocity, the decrease of net mesh size and the decrease of larval size reflects the downstream evolutionary pathway in running waters (Fig. 4) (Statzner et al., 2010; Statzner \& Dolédec, 2011).

Although it is clear, that headwater species are rare downstream and large river species always absent from headwaters, generally two or exceptionally three species may occur together in the upper and middle sections of river networks, while several-even up to seven-species can coexist in the lower ones (Bournaud et al., 1982).

Several investigations were carried out to reveal the causes and strategies that allow Trichoptera species with similar ecological demands to occur together (e.g. Edington, 1968; Elliot, 1968; Wallace, 1975; Oswood, 1976; Williams \& Hynes, 1973; Wallace et al., 1977; Hildrew, 1978), and many of them stress the importance of microhabitat selection in the

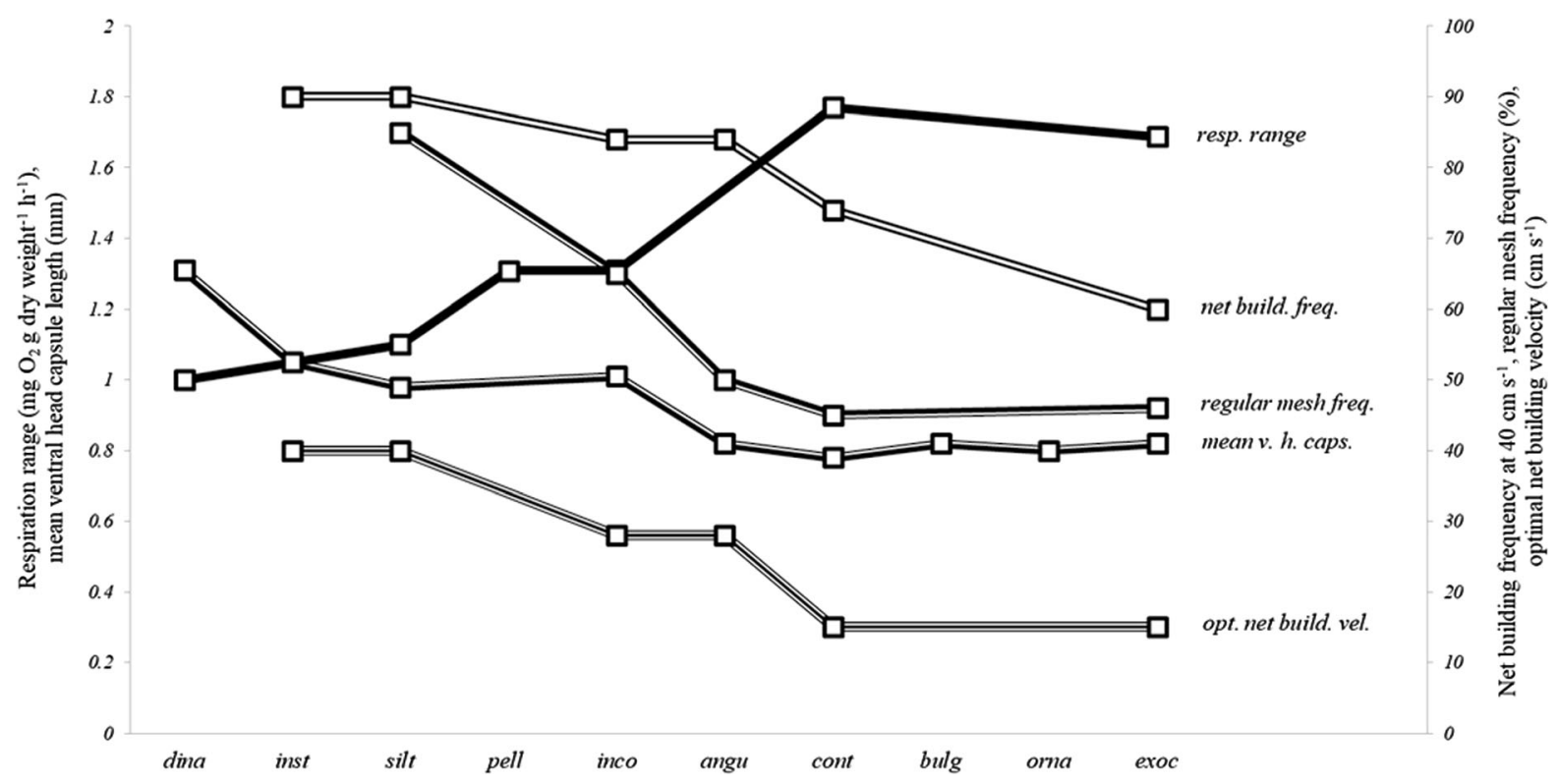

Fig. 4 Traits of some Hydropsyche species correlating with their position in the longitudinal sequence. Respiration range across $5-25^{\circ} \mathrm{C}$ (referred also as total amplitude of metabolism in the text) increases while net-building frequency and the ratio of regular meshes built at $40 \mathrm{~cm} / \mathrm{s}$, the optimal net-building velocity at which most larvae build nets with regular meshes as well as the mean ventral legth of the head capsule decreases downstream. Values of respiration range and mean ventral head capsule length are on the primary (left), others are on the secondary (right) vertical axis of the graph. (Data from Guinand et al. (1994) and Statzner \& Dolédec (2011), neighbouring points are connected in case of missing values.) 
coexistence in different ecoregions (e.g. Cudney \& Wallace, 1980; Edington et al., 1984; Urbanic \& Toman, 2005). Hildrew \& Edington (1979) points out that $H$. siltalai and $H$. pellucidula divide up netspinning sites within the same river section by partial differences in water velocity preferences, by the use of crevices of different sizes at different times (small crevices in early summer by the former and those in autumn and winter by the latter) and by the use of qualitatively different sites (e.g. those in moss or under stones). Spatial variability of net-spinning sites can also allow the coexistence with other members of Hydropsychidae, like in the case of $H$. exocellata, which is more tolerant of low current velocity, therefore was able to remain at less swift sites near the banks than in riffles, which were inhabited by Cheumatopsyche lepida (Pictet, 1834) (Dolédec \& Tachet, 1989). According to Czachorowski \& Serafin (2004), the occasionally coexisting large river species, $H$. contubernalis and $H$. bulgaromanorum, differ in their preferred habitat types as the larvae of the former were rather associated with aquatic plants, submerged parts of trees, or stones whereas those of the latter were strictly associated with large stones.

An obvious point to consider in the context of both sequential distribution and coexistence is the possible differences in net-structure and consequent specialization in diet of Hydropsyche species. Significant differences in net dimensions can be observed (1) between headwater and small stream species, which spin larger nets with thicker strands and coarse meshes, and those of larger rivers, which have smaller and finer structures with smaller mesh size; (2) in successive instars of larvae, where there is an increase both in overall measures and in mesh size (Kaiser, 1965; Williams \& Hynes, 1973; Malas \& Wallace, 1977); (3) among different genera in the family Hydropsychidae, which clearly facilitates their coexistence by partitioning food supply on the basis of particle size (Wallace, 1975; Alstad, 1982; Malas \& Wallace, 1977; Wallace et al., 1977). The same instars of syntopic Hydropsyche species (usually belonging to the same species-group), however, have similar nets and differences in their structure only appears when different instars occur together at the same time due to their staggering life cycles, as in the case of $H$. pellucidula and $H$. siltalai in the river Usk (Hildrew \& Edington, 1979).
Life histories of the Hydropsyche species show adaptability to environmental conditions and exhibit variations for one species, being influenced mainly by temperature both as a function of altitude and latitude (Dolédec \& Tachet, 1989). Various growth rates, flight periods and overwintering larval stages of a given species were observed not only in different geographical regions but even in the same river system, for example in the cases of $H$. instabilis, $H$. pellucidula, H. siltalai or H. contubernalis (Hildrew, 1978; Andersen \& Klubnes, 1983; Sieglstetter et al., 1997). These differences, including the optional change in voltinism (Tachet \& Bournaud, 1981) act as isolation mechanism for coexisting species-limited by short supply of food-via different net structures as mentioned above or different feeding habits of instars, so that species, occurring at the same site, might partition resources.

The larvae of Hydropsyche are generally omnivorous, but they can change their behaviour and choose between hunting, grazing and catching drifting food with their nets depending on the season and on the given larval instar (Burton \& McRae, 1972; Fuller \& Mackay, 1980). Net-spinning activity varies by the function of complex effect of different factors, mainly temperature and current velocity, and there are certain periods during the year, especially in winter, when larvae do not spin nets at all (Xiang et al., 1984; Poepperl, 2000). By opting to choose between different strategies in their feeding behaviour, coexisting species may reduce interspecific competition (Sieglstetter et al., 1997), which, in case it appears, often results in character displacement or the retardation of the development of larvae. Both phenomena were observed in the favour of $H$. pellucidula when coexisting with $H$. siltalai (Andersen \& Klubnes, 1983; Czachorowski, 1989). Gut content analyses showed that although the qualitative composition of food may change during larval instars, it is basically the same when similar instars of different species are compared (Hildrew \& Edington, 1979). Differences observed in mesh size in the nets of larvae at different stages of growth appear to be related more to the selection of different kinds of food then to the selection of particles of any given size (Georgian \& Wallace, 1981; Merritt \& Wallace, 1981).

hydropsychidae are known to be quite territorial species; they are not only aggressive against other filter-feeders and congeneric species but also exhibit 
intraspecific aggressive behaviour (Schuhmacher, 1970). The head size of the final instar affects the superiority of a given species over others, by the means of both its success to invade larval retreats of other species and defending its own retreat against invaders, and this superiority increases significantly with head length (Pierrot, 1984). Experimental evidences showed that larvae of $H$. angustipennis, $H$. siltalai and $H$. pellucidula fight vigorously about the ownership of a retreat either as intruders or defenders and also proved that victory of any party positively depends on the size of the combatant (Jansson \& Vuoristo, 1979; Gatley, 1988). Losers of such fights typically escape by drift (Schuhmacher, 1970), so it has an indirect effect on larval dispersal via niche shifts or species exclusions, and which should be related to size (Statzner \& Dolédec, 2011). It is also observed, that several species of Hydropsyche stridulate by running their fore femurs across ridges on the underside of their head when encountered with intruders of their retreat, especially in case of conspecific intruders, and that stridulation, which can also be provoked easily by nonspecific artificial stimuli, thus classed as protest sounds, increases defensive success (Jansson \& Vuoristo, 1979). Fighting and stridulation, however, do not seem to have function in spacing or regulating population density as in natural conditions larvae often build their retreats side by side, sometimes even with common walls, and in such cases fighting only occurs when the larvae start building their retreats but ceases soon after. Stridulation by specimens in their own retreats is only responded by others when the shelters have common walls, and it can continue in an alternating way for hours, however, no fighting were observed in these cases, and the specimens remained in their closely situated retreats for weeks (Jansson \& Vuoristo, 1979).

\section{Conclusions}

Longitudinal distribution of Hydropsyche species along the stream-river continuum shows a distinctive zonation or overlapping sequence, which is a result of adaptation to downstream gradients in the environment, generally occurring in riverine ecosystems (Statzner et al., 2010). Increasing annual mean water temperature and its range, along with decreasing nearbottom current velocity and decreasing grain size of bottom sediments are primarily related to differing species traits, such as temperature-dependent respiration, velocity preference or filter-net-building behaviour of species living in different river sections. These traits, in addition, can be strongly linked to the phylogeny of the genus, which indicates the tendency of more frequent downstream evolutionary steps and results in closer phylogenetic relationship of species living closer to each other than those that live further in the sequence form headwaters to estuaries (Statzner \& Dolédec, 2011).

The position of the species in the overlapping sequence is more or less restricted, so different stream and river stretches have characteristic species or the combination of them, which-especially in the case of less tolerant, ecologically more demanding taxamakes them suitable bio-indicator organisms.

Coexistence of species in the overlapping zones of their longitudinal distribution is common and facilitated mostly by partitioning of food supply and netspinning sites, based on qualitative or spatial differences, as well as on staggering life cycles. Specimens of different species at mutually inhabited sites could also use physical aggression and stridulation for the sake of a successful fight for larval retreats or free netspinning sites. Exploring and defining the ways and rules of coexistence among hydropsychidaecould help learning the organization and function of community structures.

Deviations from the naturally established sequences and/or assemblages of species, let alone the appearance or expansion of euryecious taxa suggests adverse changes of the stream reach or section in question, including its hydromorphological, physical, chemical or trophic properties, as well as the ecological status of its surroundings. The exact ranges of several physical, chemical and habitat- or landscape-related environmental parameters, preferred by certain species, however, are mostly unknown, and wait for further investigations. Expanding and improving the knowledge about the peculiar and ecologically extremely meaningful longitudinal pattern that the distribution of hydropsychidaeexhibit, identifying the essential habitats of species or discovering the relationship between environmental variables and their distributional patterns not only can forward a better understanding of the underlying processes of stream ecology and riverine ecosystems, but also holds the possibility to use acquired experimental results in 
water quality assessment or species distribution modelling (SDM) to investigate, model or forecast how species' distributions can be affected by the changes or alterations in their environment, inducted by natural causes, anthropogenic impact or climate change.

Acknowledgements We would like to thank Dr. Arnold Móra and two anonymous reviewers for their valuable comments and suggestions that helped to improve the manuscript.

Author contributions Idea for the article: MF, ZC; Literature research: MF; Writing —original draft preparation: MF; Critical revision: $\mathrm{ZC}$.

Funding Open access funding provided by University of Pécs. MF was supported by the funds and personal grants of the Biology and Sportbiology doctoral programme of the Faculty of Sciences of the University of Pécs, ZC acknowledge funding by the Higher Education Institutional Excellence Programme of the Ministry of Human Capacities in Hungary, within the framework of the 20765-3/2018/FEKUTSTRAT and TUDFO/ 47138/2019-ITM 'Innovation for sustainable and healthy living and environment' thematic programme of the University of Pécs.

\section{Declarations}

Conflict of interest The authors have no conflicts of interest to declare that are relevant to the content of this article.

Open Access This article is licensed under a Creative Commons Attribution 4.0 International License, which permits use, sharing, adaptation, distribution and reproduction in any medium or format, as long as you give appropriate credit to the original author(s) and the source, provide a link to the Creative Commons licence, and indicate if changes were made. The images or other third party material in this article are included in the article's Creative Commons licence, unless indicated otherwise in a credit line to the material. If material is not included in the article's Creative Commons licence and your intended use is not permitted by statutory regulation or exceeds the permitted use, you will need to obtain permission directly from the copyright holder. To view a copy of this licence, visit http://creativecommons.org/licenses/by/4.0/.

\section{References}

Alstad, D. N., 1980. Comparative biology of the common Utah Hydropsychidae (Trichoptera). American Midland Naturalist 103: 167-174.

Alstad, D. N., 1982. Current speed and filtration rate link caddisfly phylogeny and distributional patterns on a stream gradient. Science 216: 553-554.

Andersen, T. \& R. Klubnes, 1983. The life histories of Hydropsyche siltalai Döhler, 1963 and H. pellucidula (Curtis, 1834) (Trichoptera, Hydropsychidae) in a West Norvegian river. Aquatic Insects 5: 51-62.
Araújo, M. B. \& A. Guisan, 2006. Five (or so) challenges for species distribution modelling. Journal of Biogeography 33: 1677-1688.

Ashcroft, M. B., K. French \& L. Chisholm, 2011. An evaluation of environmental factors affecting species distributions. Ecological Modelling 222: 524-531.

Badcock, R. M., 1974. The distribution of the Hydropsychidae in Britain. In Malicky, H. (ed), Proceedings of the First International Symposium on Trichoptera. Dr. W. Junk Publishers, The Hague: 49-58.

Bales, M. T. \& R. M. Badcock, 1987. Respiratory rates and distribution of caddis larvae in relation to acclimation to temperature. In Bournaud, M. \& H. Tachet (eds), Proceedings of the 5th International Symposium on Trichoptera. Dr. W. Junk Publishers, The Hague: 49-58.

Barata, C., I. Lekumberri, M. Vila-Escale, N. Prat \& C. Porte, 2005. Trace metal concentration, antioxidant enzyme activities and susceptibility to oxidative stress in the Trichoptera larvae Hydropsyche exocellata from the Llobregat river basin (NE Spain). Aquatic Toxicology 74: 3-19.

Bäthe, J. \& E. Coring, 2011. Biological effects of anthropogenic salt-load ont he aquatic fauna: a synthesis of 17 years of biological survey on the rivers Werra and Weser. Limnologica 41: 125-133.

Becker, G., 1987. Net-building behaviour, tolerance and development of two caddisfly species from the river Rhine (Hydropsyche contubernalis and $H$. pellucidula) in relation to the oxygen content. Oecologica 73: 242-250.

Bonada, N., C. Zamora-Muñoz, M. Rieradevall \& N. Prat, 2004. Trichoptera (Insecta) collected in Mediterranean river basins of the Iberian Peninsula: taxonomic remarks and notes on ecology. Graellsia 60: 41-69.

Bonada, N., S. Vives, M. Rieradevall \& N. Prat, 2005. Relationship between pollution and fluctuating asymmetry in the pollution-tolerant caddisfly Hydropsyche exocellata (Trichoptera, Insecta). Archiv für Hydrobiologie 162: 167-185.

Boon, P. J., 1978. The pre-impoundment distribution of certain Trichoptera larvae in the North Tyne river system (northern England) with particular reference to current speed. Hydrobiologia 57: 167-174.

Bornette, G. \& S. Puijalon, 2011. Response of aquatic plants to abiotic factors: a review. Aquatic Sciences 73: 1-14.

Botosaneanu, L. \& H. Malicky, 1978. Trichoptera. In Illies, J. (ed), Limnofauna Europaea. A Checklist of the Animals Inhabiting European Inland Waters, with an Account of Their Distribution and Ecology, 2nd ed. Gustav, Stuttgart: 333-359.

Boulangeat, I., D. Gravel \& W. Thullier, 2012. Accounting for dispersal and biotic interactions to disentangle the drivers of species distributions and their abundances. Ecology Letters 15: 584-593.

Bournaud, M., H. Tachet \& J. F. Perrin, 1982. Les Hydropsychidae (Trichoptera) du Haut-Rhône entre Genève et Lyon. Annales de Limnologie 18: 61-80.

Buczyńska, E., 2013. The influence of a dam reservoir on caddisflies (Trichoptera) of an upland river on the example of the River Bystrzyca (south-eastern Poland). Ochrona Środoviska I Zasobów Naturalnych 24: 17-22.

Burton, G. J. \& T. M. McRae, 1972. Observation on Trichoptera predators of aquatic stages of Simulium damnosum and 
other Simulium species in Ghana. Journal of Medical Entomology 9: 289-294.

Camargo, J. A., 1991. Ecotoxicological study on the influence of an industrial effluent on a net-spinning caddisfly assemblage in a regulated river. Water, Air and Soil Pollution 60: 263-277.

Camargo, J. A., A. Alonso \& A. Salamanca, 2005. Nitrate toxicity to aquatic animals: a review with new data for freshwater invertebrates. Chemosphere 58: 1255-1267.

Cardinale, B. J., E. R. Gelmann \& M. A. Palmer, 2004. Net spinning caddisflies as stream ecosystem engineers: the influence of Hydropsyche on benthic substrate stability. Functional Ecology 18: 381-387.

Chase, J. M. \& M. A. Leibold, 2003. Ecological niches: Linking classical and contemporary approaches. University of Chicago Press, Chicago.

Cogo, G. B., J. Martínez, S. Santos \& M. A. S. Graça, 2020. Caddisflies growth and size along an elevation/temperature gradient. Hydrobiologia 847: 207-216.

Coppa, G., 2015. Addition à la faune des Trichoptères de France: découverte de la larve d'Hydropsyche silfvenii Ulmer, 1906 dans le département des Ardennes (N-E France) [Trichoptera, Hydropsychidae]. Ephemera 17: 37-42.

Cudney, M. D. \& J. B. Wallace, 1980. Life cycles, microdistribution and production dynamics of net spinning caddisflies in a large southeastern (USA) river. Holarctic Ecology 3: 169-182.

Cummins, K. W., 1973. Trophic relations of aquatic insects. Annual Review of Entomology 18: 183-206.

Cummins, K. W., 1974. Structure and function of stream ecosystems. BioScience 24: 631-641.

Czachorowski, S., 1989. Differentiation of the habitats of Hydropsychidae larvae (Insecta: trichoptera) in the Pasłęka river as a result of avoidance of trophic competition. Polskie Archiwum Hydrobiologii 36: 123-132.

Czachorowski, S. \& E. Serafin, 2004. The distribution and ecology of Hydropsyche bulgaromanorum and Hydropsyche contubernalis (Trichoptera: Hydropsychidae) in Poland and Belarus. Lauterbornia 50: 85-98.

De Soto, J., M. Fernández-Aláez, E. Luis-Calabuig \& C. Fernández-Aláez, 1994. Spatial and temporal distribution of the caddisfly (Trichoptera) communities of the Sil basin (NW Spain). Internationale Vereinigung für theoretische und angewandte Limnologie: Verhandlungen 253: 1716-1722.

Décamps, H., 1968. Vicariance écologique chez les Trichoptères des Pyrénées. Annales de Limnologie 4: 1-50.

Dohet, A., 2002. Are caddisflies an ideal group for the biological assessment of water quality in streams? In Mey, W. (ed), Proceedings of the 10th International Symposium on Trichoptera, Potsdam, Germany. Nova Supplementa Entomologica, Keltern 15: 507-520.

Dolédec, S. \& H. Tachet, 1989. Ecological observations and life histories of five net-spinning caddisflies (Trichoptera) of the Lower Adèche river. Aqiatic Insects 11: 89-99.

Dolédec, S., J. M. Olivier \& B. Statzner, 2000. Accurate description of the abundance of taxa and their biological traits in stream invertebrate communities: effects of taxonomic and spatial resolution. Archiv für Hydrobiologie 148: $25-43$.
Dunson, W. \& J. Travis, 1991. The role of abiotic factors in community organization. The American Naturalist 138: 1067-1091.

Edington, J. M., 1965. The effect of water flow on populations of net-spinning Trichoptera. Mitteilungen Internationale Vereinigung für theoretische und angewandte Limnologie 13: $40-48$.

Edington, J. M., 1968. Habitat preferences in net-spinning caddis larvae with special reference to the influence of water velocity. Journal of Animal Ecology 37: 675-692.

Edington, J. M. \& M. A. Edington \& J. A. Dorman, 1984. Habitat partitioning amongst Hydropsychid larvae of a Malaysian stream. In Morse, J. C. (ed), Proceedings of the 4th International Symposium on Trichoptera. Dr. W. Junk Publishers, The Hague: 123-129.

Edington, J. M. \& A. G. Hildrew, 1973. Experimental observations relating to the distribution of net-spinning Trichoptera in streams. Verhandlungen der internationale Vereinigung für theoretische und angewandte Limnologie 18: $1549-1558$.

Edington, J. M. \& A. G. Hildrew, 1995. A revised key to the caseless caddis larvae of the British Isles, with notes on their ecology. Freshwater Biological Association Scientific Publications 53: 1-119.

Elliot, J. M., 1968. The life histories and drifting of Trichoptera in a Dartmoor stream. The Journal of Animal Ecology 37: 615-625.

Engels, S., D. Neumann, H. Löbbel \& M. Brühne, 1996. Waiting for Hydropsyche - why has only one of at least four local Hydropsyche species returned into the Lower Rhine? Large Rivers 10: 313-314.

Englmaier, G. K., D. S. Hayes, P. Meulenbroek, Y. Terefe, A. Lakew, G. Tesfaye, H. Waidbacher, H. Malicky, A. Wubie, P. Leitner \& W. Graf, 2020. Longitudinal river zonation in the tropics: examples of fish and caddsiflies front he endorheic Awash River, Ethiopia. Hydrobiologia 847: 4063-4090.

European Commission, 2000. Directive 2000/60/EC of the European Parliament and of the Council of 23 October 2000 establishing a framework for community action in the field of water policy. Offline Journal of the European Communities 2000.

Faith, D. P. \& R. H. Norris, 1989. Correlation of environmental variables with patterns of distribution and abundance of common and rare freshwater macroinvertebrates. Biological Conservation 50: 77-98.

Friberg, N., J. Skriver, S. E. Larsen, M. L. Pedersen \& A. Buffagni, 2010. Stream macroinvertebrate occurance along gradients in organic pollution and eutrophication. Freshwater Biology 55: 1405-1419.

Fuller, R. L. \& R. J. Mackay, 1980. Feeding ecology of three species of Hydropsyche (Trichoptera: Hydropsychidae) in southern Ontario. Canadian Journal of Zoology 58: 2239-2251.

Fuller, R. L., R. J. Mackay \& H. B. N. Hynes, 1983. Seston capture by Hydropsyche betteni nets (Trichoptera, Hydropsychidae). Archiv für Hydrobiologie 97: 251-261.

Gallardo-Mayenco, A. \& A. Ruíz, 2007. Distribution and microhabitat selection of Hydropsyche exocellata Dufour (Trichoptera, Hydropsychidae) in a Mediterranean river 
affected of organic pollution: the Guadaria River (S Spain). Limnetica 26: 89-97.

Gallardo-Mayenco, A., J. Prenda \& J. Toja, 1998. Spatio-temporal distribution and ecological preferences of coexisting hydropsychid species (Trichoptera) in two mediterranean river basins (S Spain). International Review of Hydrobiology 83: 123-134.

Gatley, G. K., 1988. Competition and the structure of hydropsychid guilds in southern Sweden. Hydrobiologia 164: 23-32.

Georgian, T. J. \& J. B. Wallace, 1981. A model of seston capture by net-spinning caddsiflies. Oikos 36: 147-157.

Geraci, C. J., X. Zhou, J. C. Morse \& K. M. Kjer, 2010. Defining the genus Hydropsyche (Trichoptera: Hydropsychidae) based on DNA and morphological evidence. Journal of the North American Benthological Society 29: 918-933.

González-Salazar, C., C. R. Stephens \& P. A. Marquet, 2013. Comparing the relative contributions of biotic and abiotic factors as mediators of species' distributions. Ecological Modelling 248: 57-70.

Gordon, A. E. \& J. B. Wallace, 1975. Distribution of the family Hydropsychidae (Trichoptera) in the Savannah river basin of North Carolina, South Carolina and Georgia. Hydrobiologia 46: 405-423.

Graf, W., J. Murphy, J. Dahl, C. Zamora-Muñoz, \& M. J. LópezRodríguez, 2008. Distribution and ecological preferences of European freshwater organisms. Vol. 1. Trichoptera. In Schmidt-Kloiber, A. \& D. Hering (eds), Distribution and ecological preferences of European freshwater organisms. Pensoft, Sofia-Moscow.

Guinand, B., H. Tachet \& C. Roux, 1994. Longitudinal distribution and ecophysiological characteristics of Hydropsyche exocellata (Trichoptera: Hydropsychidae) in large rivers. Ecography 17: 189-197.

Hauer, F. R. \& J. A. Stanford, 1982. Ecology and life histories of three net-spinning caddisfly species (Hydropsychidae: Hydropsyche) in the Flathead River, Montana. Freshwater Invertebrate Biology 1: 18-29.

Hellawell, J. M., 1986. Biological indicators of freshwater pollution and environmental management. Elsevier, London.

Hesthagen, T., A. Fjellheim, A. K. Achartau, R. F. Wright, R. Saksgård \& B. O. Rosseland, 2011. Chemical and biological recovery of Lake Saudlandsvatn, a formerly highly acidified lake in southernmost Norway, in response to decreased acid deposition. Science of the Total Environment 409: 2908-2916.

Higler, L. W. G. \& H. H. Tolkamp, 1983. Hydropsychidae as bio-indicators. Environmental Monitoring and Assessment 3: 331-341.

Higler, B., H. Spijkers \& P. Van Wielink, 2008. A two-year survey of Trichoptera caught on light in the Kaaistoep (The Netherlands). Entomologische Berichten 68: 175-181.

Hildrew, A. G., 1978. Ecological aspects of lifehistory in some net-spinning Trichoptera. In Crichton, M. I. (ed), Proceedings of the 2nd International Symposium on Trichoptera. Dr. W. Junk Publishers, The Hague: 269-281.

Hildrew, A. G. \& J. M. Edington, 1979. Factors facilitating the coexistence of Hydropsychid caddis larvae (Trichoptera) in the same river system. Journal of Animal Ecology 48: 557-576.
Houghton, A., 2004. Utility of caddisflies (Insecta: Trichoptera) as indicators of habitat disturbance in Minnesota. Journal of Freshwater Ecology 19: 97-108.

Howell, D. \& J. Voshhell, 1982. The effects of body weight and temperature on the metabolic rate of Hydropsyche venularis Banks (Trichoptera: Hydropsychidae). Comparative Biochemistry and Physiology 71: 401-405.

Hrovat, M. \& G. Urbanič, 2012. Life cycle of Rhyacophila fasciata Hagen, 1859 and Hydropsyche saxonica McLachlan, 1884 in a Dinaric karst river system. Aquatic Insects 34: 113-125.

Hutchinson, G. E., 1957. Concluding remarks. Cold Spring Harbor Symposia on Quantitative Biology 22: 415-427.

Hynes, H. B. N., 1970. The Ecology of Running Waters. University of Toronto Press, Toronto.

Illies, J., 1961. Versuch einer allgemeinen biozönotischen Gliederung der Fließgewässer. Internationale Revue der gesmten Hydrobiologie und Hydrographie 46: 205-213.

Illies, J. 1978. Limnofauna Europaea. A checklist of the animals inhabiting European inland waters, with an account of their distribution and ecology. 2nd Edition. Gustav Fischer Verlag, Stuttgart.

Jackson, D. A., P. R. Peres-Neto \& J. D. Olden, 2001. What controls who is where in freshwater fish communities-the roles of biotic, abiotic and spatial factors. Canadian Journal of Fisheries and Aquatic Sciences 58: 157-170.

Jansson, A. \& T. Vuoristo, 1979. Significance of stridulation in larval Hydropsychidae (Trichoptera). Behaviour 71: $167-186$.

Kaiser, P., 1965. Über Netzbau un Strömungssinn bei der Larven der Gattung Hydropsyche Pict. (Ins., Trichoptera). Internationale Revue der gesamten Hydrobiologie und Hydropgraphie 50: 169-224.

Lechthaler, W. \& W. Stockinger, 2005. Trichoptera-Key to Larvae from Central Europe. DVD Edition, Vienna.

Leclercq, L. \& B. Maquet, 1987. Deux noveaux indices chimique et diatomique de qualité de l'eau courante. Application au Samson et à ses affluents (Bassin de la Meuse Belge). Comparison avec d'autres indices chimique, biocénotique et diatomique. Documents de travail de l'Institut Royal des Sciences naturelles de Belgique 38: 3-112.

Li, J., A. Herlihy, W. Gerth, P. Kaufmann, S. Gregory, S. Urquhart \& D. P. Larsen, 2001. Variability in stream macroinvertebrates at multiple spatial scales. Freshwater Biology 46: 87-97.

Li, L., B. Zheng \& L. Liu, 2010. Biomonitoring and bioindicators used for river ecosystems: definitions, approaches and trends. Procedia Environmental Sciences 2: 1510-1524.

MacArthur, R. \& R. Levins, 1967. The limiting similarity, convergence, and divergence of coexisting species. American Naturalist 101: 377-385.

Maguire, Z., B. B. Tumolo \& L. K. Albertson, 2020. Retreat but no surrender: net-spinning caddisfly (Hydropsychidae) silk has enduring effects on stream channel hydraulics. Hydrobiologia 847: 1539-1551.

Malas, D. \& J. B. Wallace, 1977. Strategies for coexistence in three species of net-spinning caddisflies (Trichoptera) in second-order southern Appalachian streams. Canadian Journal of Zoology 55: 1829-1840. 
Malicky, H., 1977. Ein Beitrag zir Kenntnis der Hydropsyche guttata-Gruppe (Trichoptera, Hydropsychidae). Zeitschrift der Arbeitsgemeinschaft Österreichischen Entomologen 29: 1-28.

Malicky, H., 2014. Hydropsyche tobiasi. The IUCN Red List of Threatened Species 2014: e.T10332A21426347.

Malicky, H. \& P. Chantaramongkol, 2000. Ein Beitrag zur Kenntnis asiatischer Hydropsyche-Arten (Trichoptera, Hydropsychidae) (Zugleich Arbeit Nr. 29 über thailändische Köcherfliegen). Linzer Biologische Beiträge 32: 791-860.

Malmqvist, B., 2002. Aquatic invertebrates in riverine landscapes. Freshwater Biology 47: 679-694.

Merritt, R. W. \& B. J. Wallace, 1981. Filter-feeding insects. Scientific American 244: 132-147.

Mishall, G. W., K. W. Cummins, R. C. Petersen, C. E. Cushing, D. A. Burns, J. R. Sedell \& R. L. Vannote, 1985. Developments in stream ecosystem theory. Canadian Journal of Fisheries and Aquatic Sciences 42: 1045-1055.

Neu, P. J. \& J. Fischer, 2002. The larva of Hydropsyche botosaneanui Marinkovic-Gospodnetic 1966 (Trichoptera, Hydropsychidae). Lauterbornia 43: 95-100.

Neu, P. J. \& W. Tobias, 2004. The identification of the German Hydropsychidae (Insecta: Trichoptera). Lauterbornia 51: $1-68$.

Oswood, M. W., 1976. Comparative life histories of the Hydropsychidae (Trichoptera) in a Montana lake outlet. American Misland Naturalist 96: 493-497.

Philipson, G. N., 1954. The effect of water flow and oxygen concentration on six species of caddis fly (Trichoptera) larvae. Proceedings of the Zoological Society of London 124: 547-564.

Philipson, G. N., 1969. Some factors affecting the net-spinning of the Caddis fly Hydropsyche instabilis Curtis (Trichoptera, Hydropsychidae). Hydrobiologia 34: 369-377.

Philipson, G. N. \& B. H. S. Moorhouse, 1974. Observations on ventilatory and net-spinning acitvities of larvae of the genus Hydropsyche (Trichoptera, Hydropsychidae) under experimental conditions. Freshwater Biology 4: 525-533.

Pierrot, J.-P., 1984. Etude expérimentale de la niche écologique larvaire de quelques espèces d'Hydropsyche (Trichoptera, Hydropsychidae). Thése Doctorat Spécialité, Univeristé Lyon 1.

Pîrvu, M., C. Zaharia, A. Satmari \& L. Pârvulescu, 2015. Spatial ecology of Hydropsyche incognita (Trichoptera: Hydropsychidae) in the Carpathians. European Journal of Entomology 112: 106-113.

Piscart, C., A. Lecerf, P. Usseglio-Polatera, J.-C. Moreteau \& J.N. Beisel, 2005. Biodiversity patterns along a salinity gradient: the case of net-spinning caddisflies. Biodiversity and Conservation 14: 2335-2349.

Pitsch, T., 1993. Zur Larvaltaxonomie, Faunistik und Ökologie mitteleuropäischer Fließwasser-Köcherfliegen (Insecta: Trichoptera). Landschaftsentwicklung und Umweltforschung-Schriftenreihe des Fachbereichs Landschaftsentwicklung-Sonderheft S 8. Technische Universität, Berlin.

Poepperl, R., 2000. The filter feeders Hydropsyche angustipennis and $H$. pellucidula (Trichoptera: Hydropsychidae) in a Northern German lowland stream: microdistribution, larval development emergence pattern and secondary production. Limnologica 30: 65-72.

Puig, M. A., G. González \& L. Recasens, 1987. Modelos de distribucion de Plecopteros, Efemeropteros Tricopteros y Simulidos en el rio Ter. Limnetica 3: 125-132.

Regerand, T. I., Z. A. Nefedova, L. T. Toivonen, L. V. Dubrovina, K.-M. Vuory, L. V. Markova \& T. R. Ruokolainen, 2002. Lipid metabolism of caddisfly larvae at low $\mathrm{pH}$. Russian Journal of Developmental Biology 33: 236-241.

Resh, V. H. \& D. M. Rosenberg, 1993. Freshwater Biomonitoring and Benthic Macroinvertebrates. Chapman \& Hall, New York.

Richards, C., R. J. Haro, L. B. Johnson \& G. E. Host, 1997. Catchment and reach-scale properties as indicators of macroinvertebrate species traits. Freshwater Biology 37: 219-230.

Robert, B., 2004. Systematisches Verzeichnis der Köcherfliegen (Trichoptera) Deutschlands. Fortschreibung 02/2004. Entomologie Heute 16: 93-107.

Ross, D. H. \& J. B. Wallace, 1982. Factors influencing the longitudinal distribution of larval Hydropsychidae (Trichoptera) in a southern Appalachian stream system (U.S.A.). Hydrobiologia 96: 185-199.

Roux, C., H. Tachet, M. Bournaud \& B. Cellot, 1992. Stream continuum and metabolic rate in the larve of five species of Hydropsche (Trichoptera). Ecography 15: 70-76.

Sala, M., M. Faria, I. Sarasúa, C. Barata, N. Bonada, S. Brucet, L. Llenas, S. Ponsá, N. Prat, A. M. V. M. Soares \& M. Cañedo-Arguelles, 2016. Chloride and sulphate toxicity to Hydropsyche exocellata (Trichoptera, Hydropsychidae): Exploring intraspecific variation and sub-lethal endpoints. Science of the Total Environment 566-567: 1032-1041.

Schmidt-Kloiber, A., P. J. Neu, M. Malicky, F. Pletterbauer, H. Malicky \& W. Graf, 2017. Aquatic biodiversity in Europe: a unique dataset on the distribution of Trichoptera species with important implications for conservation. Hydrobiologia 797: 11-27.

Schoener, T. W., 1989. The ecological niche. In Cherrett, J. M. (ed), Ecological Concepts: The Contribution of Ecology to an Understanding of the Natural World. Blackwell Scientific Publications, Cambridge: 79-114.

Schuhmacher, H., 1970. Untersuchungen zur Taxonomie, Biologie und Ökologie einiger Köcherfliegenarten der Gruppe Hydropsychidae. Internationale Revue der gesamten Hydrobiologie und Hydrographie 55: 511-557.

Sieglstetter, R., F. Agasse \& T. Caquet, 1997. Ecological sgregation of two species of Hydropsyche (Trichoptera: Hydropsychidae) in a European second-order stream (Essonne, France). Journal of Freshwater Ecology 12: 269-279.

Soberón, J. M., 2010. Niche and area of distribution modelling: a population ecology perspective. Ecography 33: 159-167.

Solà, C., M. Burgos, A. Plazuelo, J. Toja, M. Plans \& N. Prat, 2004. Heavy metal bioaccumulation and macroinvertebrate community changes in a Mediterranean stream affected by acid mine drainage and an accidental spill (Guadiamar River, SW Spain). Science of the Total Environment 333: 109-126.

Statzner, B., 1987. Characteristics of Lotic Ecosystems and Consequences for Future Research Directions. In Schulze, 
E. D. \& H. Zwölfer (eds), Potentials and Limitations of Ecosystem Analysis. Ecological Studies (Analysis and Synthesis), vol. 61. Springer, Berlin: 365-390.

Statzner, B. \& S. Dolédec, 2011. Phylogenetic, spatial and species-trait patterns across environmental gradients: the case of Hydropsyche (Trichoptera) along the Loire River. International Review of Hydrobiology 96: 121-140.

Statzner, B., C. J. Douady, L. Konecny \& S. Dolédec, 2010. Unravelling phylogenetic relationships among regionally co-existing species: Hydropsyche species (Trichoptera: Hydropsychidae) in the Loire River. Zootaxa 2556: 51-68.

Sternberg, H., 1875. Untersuchungen über längen- ung querprofil geschiebeführender flüss. Zeitschrift für Bauwesen 25: 483-506.

Stuijfzand, S. C., S. Engels, E. van Ammelrooy \& M. Jonker, 1999. Caddisflies (Trichoptera: Hydropsychidae) used for evaluating water quality of large European rivers. Archives of Environmental Contamination and Toxicology 36: 186192.

Tachet, H. \& M. Bournaud, 1981. Cycles Biologiques des Hydropsychidae et D'un Polycentropodidae (Trichoptera) Dans le Rhône en Amont de Lyon. In Moretti G. P. (ed), Proceedings of the 3rd International Symposium on Trichoptera. Dr. W. Junk Publishers, The Hague: 347-364.

Tachet, H., J. P. Pierrot \& M. Bournaud, 1987. Distribution of the Hydropsyche larvae and the structure of their nets. In: Bournaud, M. \& H. Tachet (eds), Proceedings of the Fifth International Symposium on Trichoptera. Dr. W. Junk Publishers, Dordrecht: 281-286.

Tachet, H., J. P. Pierrot, C. Roux \& M. Bournaud, 1992. Netbuilding behaviour of six Hydropsyche species (Trichoptera) in relation to current velocity and dsitribution along the Rhône River. Journal of the North American Benthological Society 11: 350-365.

Tessier, L., J. L. Boisvert, L. B. Vought \& J. O. Lacoursière, 2000. Anomalies on capture nets of Hydropsyche slossonae larvae (Trichoptera, Hydropsychidae), a potential indicator of chronic toxicity of malathion (organophosphate insecticide). Aquatic Toxicology 50: 125-139.

Thuiller, W., L. J. Pollock, M. Gueguen \& T. Münkemüller, 2015. From species distributions to meta-communities. Ecology Letters 18: 1321-1328.

Urbanič, G. M. J. \& C. Krušnik Toman, 2005. Microhabitat type selection of caddisfly larvae (Insecta: Trichoptera) in a shallow lowland stream. Hydrobiologia 541: 1-12.

Urbanič, G. \& M. J. Toman, 2007. Influence of environmental variables on stream caddis larvae in three Slovenian ecoregions: Alps, Dinaric Western Balkans and Pannonian Lowland. International Review of Hydrobiology 92: 582-602.

Valladolid, M., J. J. Martínez-Bastida \& M. Arauzo, 2007. Los Hydropsychidae (Insecta: Trichoptera) del río Oja (La Rioja, España). Limnetica 26: 199-208.

van der Geest, H. G., 2007. Behavioural responses of caddisfly larvae (Hydropsyche angustipennis) to hypoxia. Contributions to Zoology 76: 250-255.

van der Geest, H. G., G. D. Greve, E. M. de Haas, B. B. Scheper, M. H. S. Kraak, S. C. Stuijfzand, K. H. Augustijn \& W. Admiraal, 1999. Survival and behavioural responses of larvae of the caddisfly Hydropsyche angustipennis to copper and diazinon. Environmental Toxicology and Chemistry 18: 1965-1971.

Vannote, R. L., G. W. Minshall, K. W. Cummins, J. R. Sedell \& C. E. Cushing, 1980. The River Continuum Concept. Canadian Journal of Fisheries and Aquatic Sciences 27: 130-137.

Vincentini, H., S. Wyler \& J. Waringer, 2020. The larva of Hydropsyche doehleri Tobias, 1972, based on Swiss material (Hydropsychidae, Trichoptera). Zootaxa 4786: $535-545$.

Vuori, K.-M., 1994. Rapid behavioural and morphological responses of hydropsychid larvae (Trichoptera, Hydropsychidae) to sublethal cadmium exposure. Environmental Pollution 84: 291-299.

Vuori, K.-M., 1995. Species- and population-specific responses of translocated hydropsychid larvae (Trichoptera, Hydropsychidae) to runoff from acid sulphate soils in the River Kyrönjoki, western Finland. Freshwater Biology 33: 305-318.

Vuori, K.-M. \& J. Kukkonen, 1996. Metal concentrations in Hydropsyche pellucidula larvae (Trichoptera, Hydropsychidae) in relation to the anal papillae abnormalities and age of exocuticle. Water Research 30: 2265-2272.

Wallace, J. B., 1975. Food partitioning in net-spinning Trichoptera larvae: Hydropsyche venularis, Cheumatopsyche etrona and Macronema zebratum. Annals of the Entomological Society of America 68: 463-472.

Wallace, J. B. \& R. W. Merritt, 1980. Filter-feeding ecology of aquatic insects. Annual Review of Entomology 25: 103-132.

Wallace, J. B. \& J. R. Webster, 1996. The role of macroinvertebrates in stream ecosystem function. Annual Review of Entomology 41: 115-139.

Wallace, J. B., J. R. Webster \& W. R. Woodall, 1977. The role of filter-feeders in flowing waters. Archiv für Hydropbiologie 79: 506-532.

Waringer, J. \& W. Graf, 1997. Atlas der österreichischen Köcherfliegenlarven. Facultas-Univeritätsverlag, Wien.

Waringer, J. \& W. Graf, 2011. Atlas der mitteleuropäischer Köcherfliegenlarven - Atlas of Central European Trichoptera Larvae. Erik Mauch Verlag, Dinkelscherben.

Weiher, E. \& P. Keddy, 1999. Ecological Assembly Rules: Perspectives, Advances, Retreat. University Press, Cambridge.

Wen, Y., G. Schoups \& N. van de Giesen, 2017. Organic pollution of rivers: combined threats of urbanization, livestock farming and global climate change. Scientific Reports 7: 43289.

Wiggins, G. \& R. J. Mackay, 1978. Some relationships between the systematics and trophic ecology in nearctic aquatic insects, with special reference to Trichoptera. Ecology 59: 1211-1220.

Williams, N. E. \& H. B. N. Hynes, 1973. Microdistribution and feeding of the net-spinning caddisflies (Trichoptera) of a Canadian stream. Oikos 24: 73-84.

Xiang, J., P. Schröder \& J. Schwoerbel, 1984. Phänologie und Nahrung der Larven von Hydropsyche angustipennis und H. siltalai (Trichoptera, Hydropsychidae) in einem Seeabfluß. Archive für Hydrobiologie Supplementband Monographische Beiträge 66: 255-292. 
Zellweger, F., A. Baltensweiler, C. Ginzler, T. Roth, V. Braunisch, H. Bugmann \& K. Bollmann, 2016. Environmental predictors of species richness in forest landscapes: abiotic factors versus vegetation structure. Journal of Biogeography 43: 1080-1090.

Zinchenko, T. D. \& L. V. Golovatyuk, 2013. Salinity tolerance of macroinvertebrates in stream waters (Review). Arid Ecosystems 3: 113-121.
Publisher's Note Springer Nature remains neutral with regard to jurisdictional claims in published maps and institutional affiliations. 